Abstracta Iranica Abstracta Iranica

Revue bibliographique pour le domaine irano-aryen

Volume 31 | 2011

Comptes rendus des publications de 2008

« Rome and Mesopotamia. Importers into India in the First Millennium AD ». Antiquity, 81, 2007, p. 972-988.

Vito Messina

(2) OpenEdition

Journals

Édition électronique

URL : http://journals.openedition.org/abstractairanica/39577

DOI : 10.4000/abstractairanica.39577

ISSN : 1961-960X

Éditeur :

CNRS (UMR 7528 Mondes iraniens et indiens), Éditions de l'IFRI

Édition imprimée

Date de publication : 15 mai 2011

ISSN : 0240-8910

Référence électronique

Vito Messina, « « Rome and Mesopotamia. Importers into India in the First Millennium AD ». Antiquity, 81, 2007, p. 972-988. », Abstracta Iranica [En ligne], Volume 31 | 2011, document 115, mis en ligne le 15 février 2012, consulté le 03 octobre 2020. URL : http://journals.openedition.org/abstractairanica/ 39577 ; DOI : https://doi.org/10.4000/abstractairanica.39577

Ce document a été généré automatiquement le 3 octobre 2020.

Tous droits réservés 


\title{
« Rome and Mesopotamia. Importers into India in the First Millennium AD ». Antiquity, 81, 2007, p. 972-988.
}

\author{
Vito Messina
}

1 Modern historians often refer to the trades between Rome and India by long-distance sea routes connecting the Mediterranean to the Indian Ocean. As is well known, a number of recent studies both of philologists and archaeologists revealed that this kind of trades were mediated by a series of important ports or outposts in the Gulf area (under the influence of both the Parthian South-Mesopotamian area or of the so-called South-Arabic kingdoms) and that these routes were sailed for the most by local ships.

2 The Author of this article promoted a program to identify systematically imported Roman amphorae in the Indian subcontinent, basing upon the review formerly compiled by S. Gupta, in which over 50 potential finding spots were listed. Although not all the reported material has yet been located, imported amphorae have been confirmed only from 31 of these sites. Furthermore, approximately the half of them also revealed that some sherds thought to belong to Roman amphorae actually belonged to a very well known Mesopotamian type of pottery, the so-called "torpedo jars", a kind of storage jar usually made in coarse or common ware, that widely diffused in the area of the Gulf starting from the Parthian Period. The presence of this Mesopotamian jars, which were not previously identified in India, reveals that both Roman and Mesopotamian products were imported into India at the same time, namely the Parthian and Sasanian Periods, and that the areas of influence of these two great imports, probably of wine, coexisted on the Indian coast. In this article, these areas are mapped for the first time. 
INDEX

Thèmes : 3.2.3. Séleucides, Parthes et Sassanides

\section{AUTEURS}

VITO MESSINA

Università di Torino 